\title{
Different Effect of Growth Hormone on the Triglyceride Metabolism in Visceral and Subcutaneous AdiposeTissues of Rats
}

Kohji Shirai, Yoshiaki Itoh, Yoh Miyashita, Hitoshi Watanabe, Hisao Tomioka and Minoru Irie Clinical Laboratory Medicine, (KS, HW), Department of Internal Medicine, (YI, YM,HT, MI), Sakura Hospital, Toho University School of Medicine, Chiba, Japan

Abstract To clarify the mechanism by which visceral adipose tissue developed in growth hormone (GH) deficient patients, and was reduced by GH supplementation, the effects of GH on the triglyceride metabolism in the visceral and subcutaneous adipose tissues of the rats were compared.

Visceral and subcutaneous adipose tissues were obtained from omentum and abdominal wall. $\left[{ }^{14} \mathrm{C}\right]$ deoxyglucose uptake and the triglyceride synthetic activity from $\left[{ }^{14} \mathrm{C}\right]$ oleic acid, and heparin-releasable lipoprotein lipase activity were not changed by the addition of $\mathrm{GH}(10 \mathrm{ng} / \mathrm{mL})$ in both visceral and subcutaneous adipose tissues, but the lipolysis by GH $(10 \mathrm{ng} / \mathrm{mL}) \mathrm{was}$ much more remarkable in the visceral adipose tissue than in subcutaneous adipose tissue, whereas adrenaline-induced lipolysis occurred almost equally in both tissues.

These results suggest that the preponderance of visceral adipose tissue in GH deficiency might partly be due to the lack of GH-preferential lipolysis in visceral adipose tissue.

Key words: growth hormone, lipolysis, visceral adipose tissue

\section{Introduction}

In growth hormone (GH) deficiency, an increase in body fat is known to occur (1). Recently, it has been reported that the visceral fat is dominant, and is reduced by GH supplementation (2). Generally, visceral fat dominancy is associated with many coronary risk factors such as hyperlipidemia, glucose intol-

Correspondence: Dr. Kohji Shirai, Clinical Laboratory Medicine, Sakura Hospital, Toho University School of Medicine, 564-1, Shimoshizu, Sakura-shi, Chiba, 285 Japan erance, and hypertension $(3,4)$.Thus it is thought to be a risk factor for ischemic coronary heart disease. Rosén et al. (5) reported the high incidence of cardiovascular disease in panhypopituitarism patients taking routine supplement therapy, and suggested that no supplement of $\mathrm{GH}$ might contribute to it. In Japan, the study group on panhypotituitarism, supported by the Japan Ministry of Health and Welfare, reported that GH-deficient patients with panhypopituitarism supplemented with other hormones showed a high incidence of cardiovascular risk factors such as 


\section{Shirai et al.}

hyperlipidemia, diabetes mellitus, and hypertension compared with GH-normal patients (6). So, it is important to clarify the mechanism by which visceral fat accumulates in the $\mathrm{GH}$ deficient state.

As for the regulation of triglyceride metabolism in the adipose tissue, synthetic and catabolic pathways can be divided. We investigated the effects of $\mathrm{GH}$ on the $\left[{ }^{14} \mathrm{C}\right]$ deoxyglucose uptake, triglyceride synthesizing activities from $\left[{ }^{14} \mathrm{C}\right]$ oleic acids and heparinreleasable lipoprotein lipase activities of the rat visceral and subcutaneous adipose tissues, as a synthetic pathway. As a catabolic pathway, lipolytic activity with $\mathrm{GH}$ and adrenaline were compared in both adipose tissues.

\section{Materials and Methods}

\section{Animals}

The animals used were 8 weeks old Wistar strain male rats. Subcutaneous adipose tissues were obtained from the inguinal area of the abdominal wall. Visceral adipose tissues were from the omentum. The adipose tissues were kept in Dulbecco modified Eagle medium containing $10 \%$ fetal calf serum at room temperature.

\section{Materials}

Human recombinant GH was kindly provided by Sumitomo Pharmaceutical Co., Ltd. (Osaka, Japan) and Pharmacia AB (Stockholm, Sweden). Insulin was obtained from Sigma. Adrenaline was purchased from the Daiichi Pharmaceutical Co., Ltd. Fatty acids were measured by enzymatic methods using NEFA kit-U purchased from Nipponshoji Co. Ltd. (Osaka, Japan) with an autoanalyzer.

\section{Glucose Uptake}

After decapitation, the adipose tissues were removed quickly. The tissues were cut into pieces $(2 \times 2 \mathrm{~mm})$ by scissors. One hundred $\mathrm{mg}$ was placed in a test tube in $0.5 \mathrm{~mL}$ of Krebs-Ringer bicarbonate buffer ( $\mathrm{pH}$ 7.4) containing $3 \%$ bovine serum albumin. 2-deoxy $-\mathrm{D}-\left[{ }^{14} \mathrm{C}\right]$ glucose $(1 \mu \mathrm{Ci})$ was added to the medium in the presence or absence of insulin $(100 \mathrm{nM})$ or $\mathrm{GH}(10 \mathrm{ng} / \mathrm{mL})$ and the tissues were incubated for 1 hour at $37^{\circ} \mathrm{C}$. Then, the minced tissues were washed by phosphate buffer saline 3 times. The radioactivities incorporated into the tissues were counted by scintillation counter (Beckman).

\section{Triglyceride Sythesizing Activity}

Minced fat tissues (100 mg) were put into the reaction mixture containing $\left[{ }^{14} \mathrm{C}\right]$ oleic acids ( $1 \mu \mathrm{Ci}$ ), $5 \%$ bovine serum albumin in 1 $\mathrm{mL}$ of Dulbecco modified Eagle medium-10 $\mathrm{mM}$ Tris $\mathrm{HCl} \mathrm{pH} \mathrm{7.4,} \mathrm{with} 100 \mathrm{nM}$ insulin or $10 \mathrm{ng} / \mathrm{mL} \mathrm{GH}$. The reaction mixture was incubated for $60 \mathrm{~min}$ at $37^{\circ} \mathrm{C}$. The reaction was stopped by the addition of $5 \mathrm{~mL}$ of Dole' $\mathrm{s}$ extraction mixture (isopropanol:heptane: $1 \mathrm{NH}_{2} \mathrm{SO}_{4}=40: 10: 1$ ) (7). Then, $3 \mathrm{~mL}$ of heptane and $2 \mathrm{~mL}$ of water were added and were shaken. Three $\mathrm{mL}$ of heptane layer was removed and poured into another test tube. Three $\mathrm{mL}$ of $0.05 \mathrm{~N} \mathrm{NaOH}-50 \%$ ethanol mixture was added and after shaking for $5 \mathrm{~min}$, $0.5 \mathrm{~mL}$ of the upper layer was removed and the radioactivity was counted.

\section{Lipoprotein Lipase Activity}

The adipose tissue $(100 \mathrm{mg} / \mathrm{mL})$ was incubated with heparin $(10 \mu \mathrm{g} / \mathrm{mL})$ at $37^{\circ} \mathrm{C}$ for 15 min in $2 \mathrm{~mL}$ of Dullbecco modified Eagle 


\section{Preferential Lipolysis of Visceral Fat by GH}

medium. Then the lipoprotein lipase activity of the medium was assayed. The reaction mixture for measurement of lipase consisted of 20 $\mu \mathrm{g}$ of triolein emulsified with $0.02 \%$ Triton X$100,5 \%$ bovine serum albumin and high density lipoprotein ( $5 \mu \mathrm{g}$ protein) in $100 \mathrm{mM}$ Tris $\mathrm{HCl} \mathrm{pH} 8.0$ in $250 \mu \mathrm{L}$. Released free fatty acids were measured by the enzymatic method stated above.

\section{Lipolysis}

The adipose tissues were cut into pieces. One hundred $\mathrm{mg}$ of tissue was put into a medium containing $4 \%$ bovine serum albumin in $2 \mathrm{~mL}$ of Dullbecco's modified Eagle medium. GH was added from 0.1-100 ng/mL. Adrenaline was added from 0.01 to $100 \mathrm{ng} / \mathrm{mL}$. Incubation was performed for 3 hours at $37^{\circ} \mathrm{C}$. Released free fatty acids in the medium were measured by the enzymatic method as stated above.

\section{Results}

The Effect of Growth Hormone on the Triglyceride Synthesizing Pathway

The effect of GH on the triglyceride synthesizing pathways in visceral and subcutaneous adipose tissues was investgated, comparing to insulin. The $\left[{ }^{14} \mathrm{C}\right]$ deoxyglucose uptake is shown in the upper panel of Fig. 1. Insulin enhanced the glucose uptake in visceral fat, but scarcely at all in the subcutaneous adipose tissue. $\mathrm{GH}$ did not show an enhancing effect in either of the tissues.

Triglyceride synthesizing activities from $\left[{ }^{14} \mathrm{C}\right]$ oleic acids are shown in the middle panels. Insulin also enhanced the triglyceride synthesis from oleic acids only in visceral adipose
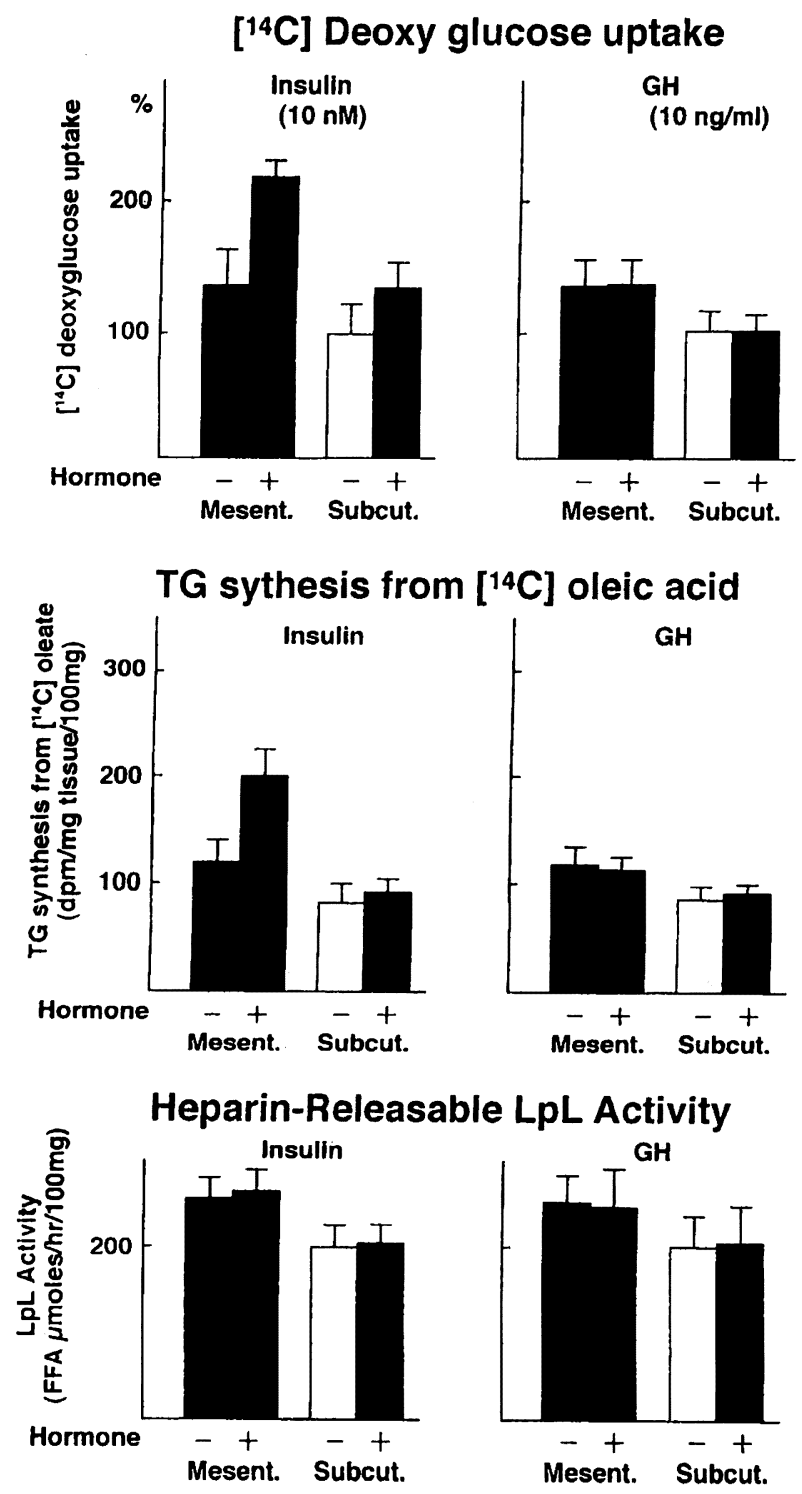

Fig. 1 Effect of insulin and growth hormone on triglyceride metabolism in mesenteric and subcutaneous adipose tissues.

The materials are shown in Materials and Methods. For $\left[{ }^{14} \mathrm{C}\right]$ deoxyglucose uptake, the incubation was performed for $60 \mathrm{~min}$. For triglyceride synthetic activities from $\left[{ }^{14} \mathrm{C}\right]$ oleic acid, the incubation was performed for 2 hours. Heparin releasable lipoprotein lipase activity was measured using the medium incubated with fat tissues and heparin( $10 \mu \mathrm{g} / \mathrm{mL}$ ) for $15 \mathrm{~min}$. 
tissue. GH did not show any effect on triglyceride synthesis from free fatty acids. Lipoprotein lipase activities released from adipose tissue with heparin are shown in the lower panel. Insulin and GH did not affected the lipoprotein lipase activity in both adipose tissues.

\section{The Effect of GH on Lipolytic Activity}

For the effect of $\mathrm{GH}$ on the catabolism of triglycerides, lipolytic activities were studied. The time course of the lipolysis is shown in Fig. 2, right. Adrenaline (10 ng/mL) enhanced the lipolytic activity both in the subcutaneous

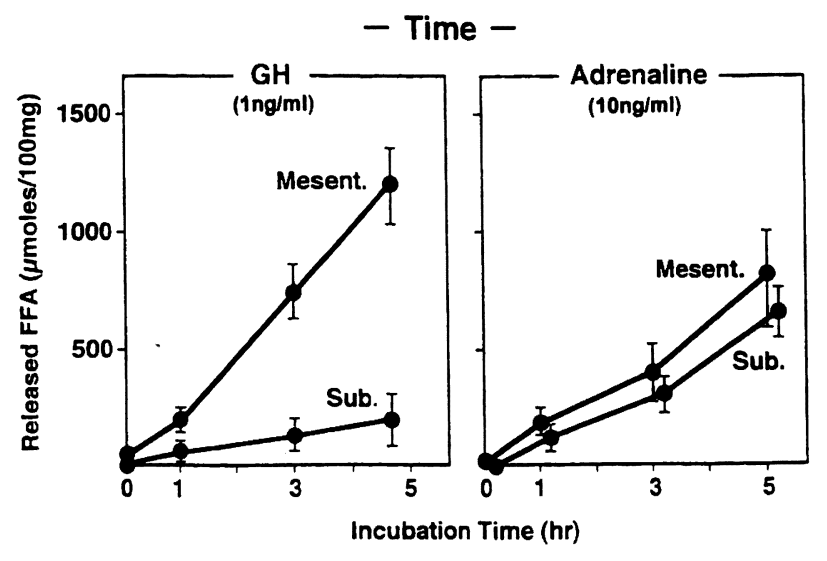

Fig. 2 Hormone-induced FFA mobilization from subcutaneous and mesentric adipose tissue

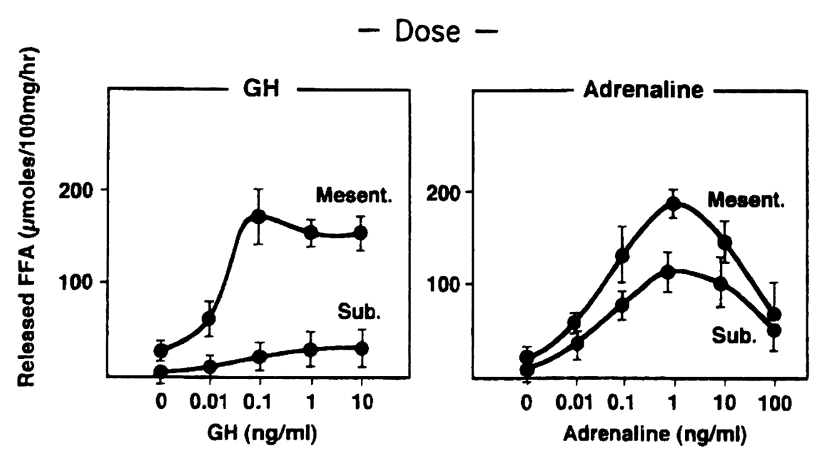

Fig. 3 Hormone-induced FFA mobilization from subcutaneous and mesenteric adipose tissue and the visceral adipose tissues. The rate was a little higher in visceral adipose tissue than in subcutaneous adipose tissue. Whereas, GH ( $1 \mathrm{ng} / \mathrm{mL}$ ) enhanced the lipolytic activity in the visceral adipose tissues predominently and scarcely at all in subcutaneous adipose tissue as shown in Fig. 2, right.

The dose effect of hormones is shown in Fig. 3. Adrenaline showed maximum activity with $1 \mathrm{ng} / \mathrm{mL}$, and a little higher in visceral adipose tissue than subcutaneous adipose tissue.

GH showed maximum activity at 0.1 $\mathrm{ng} / \mathrm{mL}$, and became a plateau above $1 \mathrm{ng} / \mathrm{mL}$. This value was nearly the concentration of the human plasma levels. The lipolytic rates by GH were far higher in the visceral adipose tissue than in the subcutaneous adipose tissue.

\section{Discussion}

As for triglyceride synthetic activity of $\mathrm{GH}$, there have been several reports $(8,9)$. Among them, the lipogenic action was reported (9). We could not observe any effect of $\mathrm{GH}$ on visceral and subcutaneous adipose tissue. GH might be lipogenic only in the GHdeprived condition. Further studies are required. In any case $\mathrm{GH}$ appeared to have little effect on the triglyceride synthesizing pathway.

Insulin promoted glucose uptake mainly in visceral adipose tissue, and also triglyceride synthesis. These results suggest that visceral adipose tissue development is promoted by insulin. This fact was also supported by the report by Inadera (10). The lipolytic action of GH had been controversial $(11,12)$ but now, 


\section{Preferential Lipolysis of Visceral Fat by GH}

direct action has been demonstrated (12). We could also demonstrate the direct action, because lipolysis did not require a lag phase.

The lipolytic activities were clearly different between visceral and subcutaneous adipose tissues, and that from the visceral fat was much more sensitive for GH than the subcutaneous one.

The mechanism by which triglyceride is hydrolyzed in adipocytes is still controversial. In the case of adrenaline, activation of hormone sensitive lipase by protein kinase $\mathrm{C}$ was proposed (13). Okuda et al. (14) proposed that phosphatidylcholine on the surface of lipid droplets might be a regulatory factor for lipolysis in fat cells, and adrenaline ruined the barrier role of the phospholipid between the substrate and hormone sensitive lipase. But the lipolytic mechanism for $\mathrm{GH}$ is not entirely clear so it is difficult to discuss the mechanism by which $\mathrm{GH}$ had different effects on visceral and subcutaneous adipose tissues. Moller et al. (15) reported that complementary deoxyribonucleic acid (cDNA) of GH was transfected into Chinese hamster ovary cells and expressed GH receptor into the cell surface, and observed enhanced lipolysis so GHinduced lipolytic activity might be mediated by $\mathrm{GH}$ receptor. The difference in the $\mathrm{GH}$-induced lipolysis between visceral and subcutaneous adipose tissues might be due to the difference of the $\mathrm{GH}$ receptor expression in both tissues. Further study is required.

In summary, it is suggested that $\mathrm{GH}$ reduced the visceral adipose tissue mainly by enhancing the lipolytic activity in the visceral adipose tissue.

Further studies are required to determine the effect of $\mathrm{GH}$ on visceral fat cell prolifera- tion and differentiation.

\section{Acknowledgment}

This work was supported in part by a research grant from the Ministry of Health and Welfare in Japan, and by the Foundation for Growth Science in Japan.

\section{References}

1. Salomon F, Cuneo RC, Hesp R, Sonksen $\mathrm{PH}$. The effects of treatment with recombinant human growth hormone on body composition and metabolism in adults with growth hormone deficiency. N Engl J Med 1989; 321: 1797-1804.

2. Bengtsson BÅ, Eden S, Lonn L, Kvist H, Stokland A, Lindstedt G, et al. Treatment of adults with growth hormone (GH) deficiency with recombinant human GH. J Clin Endocrinol Metab 1993; 76: 309-17.

3. Lapidus L, Bengtsson C, Larsson B, Pennert K, Rybo E, Sjostrom L. Distribution of adipose tissue and risk of cardiovascular disease and death: a 12 year follow up of participants in the population study of women in Gothenburg, Sweden. BMJ 1984; 289: 1257-61.

4. Ster MP, Haffner SM. Body fat distribution and hyperinsulinemia as risk factors for diabetes and cardiovascular disease. Arteriosclerosis 1986; 6: 123-30.

5. Rosen T, Bengtsson BÅ. Premature mortality due to cardiovascular disease in hypopituitarism. Lancet 1990; 336: 285-8.

6. Irie M, Miyashita Y, Itoh Y, Shirai K. The complications in panhypopituitarism in Japan, in Report of study group of Min- 
istry of Health and Welfare on Hypopituitarism. 1994: 37-9.

7. Dole VP. A relation between non-esterified fatty acid in plasma, and the metabolism of them, J Clin Invest 1956; 35: 150-4.

8. Davidson MB. Effect of growth hormone on carbohydrate and lipid metabolism. Endocr Rev 1987; 8: 115-31.

9. Smal J, De Meyts P. Role of kinase C in the insulin-like effects of human growth hormone in rat adipocytes. Biochem Biophys Res Commun 1987; 147: 1232-40.

10. Inadera $H$, Ishikawa $Y$, Shirai $K$, Saito $Y$, Yoshida S. Proliferation and triglyceride synthesizing activity of fibroblast-like cells derived from epididymal and subcutaneous adipose tissue of rats. Scand J Clin Lab Med 1993; 53: 225.

11. Frigeri LG, Khoo JC, RobelG. Absence of lipolytic activity from purified human growth hormone in cultured 3T3-L1 adipocytes. Horm Res 1983; 17: 197-201.

12. Dietz J, Schwartz J. Growth hormone alters lipolysis and hormone-sensitive lipase activity in 3T3-F442A adipocytes. Metabolism 1991; 40:8, 800-6.

13. Belfrage $P$, Fredrikson G, Olsson $H$, Strfors P. Hormonal regulation of adipose tissue lipolysis by reversible phosphorylation of hormone-sensitive lipase. Prog Clin Biol Res 1982; 102: 213-23.

14. Okuda H, Saito Y, Matsuoka N, Takeda $\mathrm{E}$, Kumagai A. Role of phospholipid in adrenaline-induced lipolysis and cyclic AMP production. J Biochem 1978; 83: 88792.

15. Möller C, Emtner M, Arner P, Norstedt G. Growth hormone regulation of lipid metabolism in cell transfected with growth hormone receptor cDNA. Mol Cell Endocrinol 1994;99: 111-7. 